\title{
Hidden forest figures in the Horizontal Metropolis: from placeholders to micro-biotopes. The case of Liedekerkebos.
}

\author{
Wim Wambecq \\ OSA researcher - PhD Student \\ Supervisor: Prof. Bruno de Meulder \\ Expected thesis defense: November 2016 \\ wim.wambecq@asro.kuleuven.be
}

This paper explores the power of the forest remnants in the Flemish nebulous city by looking at one specific case, the Liedekerke forest. This forest reduced significantly since the time of the Ferraris map, which is taken as a reference moment, but continues to influence life in the nebulous city due to its hidden interference with the dispersion. Five narratives are introduced that form the project definition of an intermediate forest figure. The hypothesis of this paper is that through these narratives the hidden, former Ferraris forest can become a sustainable urban figure in the nebulous city.

\section{Introduction}

This paper investigates the future of the Flemish dispersion through the hidden forest figure of Liedekerkebos, i.e. the specific urban realm that has developed in the former Ferraris forest. It has been established that there is a need for a transition towards a more sustainable Flemish dispersion. (Vlaamse Overheid, 2011) The regional and national deliberate housing policies and the hyper-individualism of the "house with a garden" dream of the last decades have resulted in a housing stock that is quasi evenly spread over the territory in a continuous patchwork of ribbon developments and open allotments. (Ryckewaert et al., 2012) This has left no room for change, for a transition to a different urban condition that can accompany the contemporary demands.

With the increasing ecological awareness in the twenty-first century the suburban development found itself in an ambiguous situation. On the one hand it was criticised for its large ecological footprint, on the other hand the sprawl as urban development continued to be the ultimate dream. The criticism of urban sprawl in the United States (Berger, 2006) opened a wide debate on sustainability of the suburban condition from which Flanders did not escape. In addition the 2007 financial crisis raised even more questions since the suburbanisation showed its unadaptness to cope with increasing social differences (Dedecker et al., 1997) and changing societal configurations. (Ryckewaert et al., 2012) Some people are no longer able to pay their energy bills, cannot afford and hardly use (all of the oversized houses and regulation does not easily allow reconversion into more flexible housing typologies and innovative collective living structures. On top of this social and ecological crisis, the Flemish suburbanisation also faces a mobility crisis. On Wednesday 10th of February 2010 the largest traffic congestion ever was recorded due to a $5 \mathrm{~cm}$ thick layer of snow. Almost $1.000 \mathrm{~km}$ traffic jam on the highways (Touring Mobilis) led to an even more astonishing $2.000 \mathrm{~km}$ on secondary roads (Social Media and GPS systems e.g. TomTom). People were stuck in traffic on their own driveway.

The once considered Flemish dream is turning into a nightmare and the current urban practice and policy lacks the capacity to deal with suburban Flanders. Where urban planning in the compact city builds strongly on the idea of important strategic projects, the requalification of suburbia will rather be one of slow (or fast if possible) transformation creating a transition to a more sustainable territory.

The former and current housing policies created a territory that is largely monotonous. (De Meulder and Dehaene, 2001) It is a carpet of ribbon development and allotments where specificity and sense of direction (isotropic territory) (Pellegrini and Viganò, 2006) are missing on the small scale and where one homogeneous urban condition is legible on the large scale, e.g the scale of the Spatial Policy Plan. Such a reading implies that all different places and localities in suburbia are equal to one and other. In reality, there is a lot of hidden diversity on an intermediate scale that is not immediately readable from the urban form, but are potential agents for urban practice: there are wet valleys and forested higher ridges, dry and wet agriculture landscapes, proximity to urban centres; there are monofunctional, low scale ribbons and multifunctional ribbons; there are urban developments with very large typologies and worker housing neighbourhoods. Various conditions make that no point in suburbia is equal to one another. This suggests that there is no generic but rather a multitude of conditions that nevertheless on the whole lack quality and raise a lot of economic as well as ecological and sustainability issues. The qualities of this multitude of conditions are indeed not valorised in the current legal structure.

This paper hypothesizes that these qualities can be realised by an intermediate field of action mediating between individual needs and sustainable collective. This intermediate is spatial, in this case specifically the hidden forest figures in the nebulous city, but also temporal, organizational... It continuously bridges different and 
diverging needs and necessities to steer suburbia towards a more sustainable environment. In order to do that, a tailor made transition management has to be generated.

Finally this paper explores 'Liedekerkebos' - the forest of Liedekerke - as one possible contribution to the transition of the nebulous city through the intermediate of a hidden forest figure. An analysis of the urban form that invaded the Ferraris forests - forests present on the 1775 Ferraris map (Lammens, 2011) - in [Fig. 1] shows that the nebulous city did not develop the same way in and around this former forest than in other places of the territory. A certain resistance against urbanization brings a moment of otherness inside the monotonous nebula that can be the pretext for a sustainable future. A forest figure that hides in the nebulous city.



[Fig. 1] Aerial image of the area with the former Ferraris forest perimeter indicated. Although subtle, the urban realm within the Ferraris forest perimeter is different. Source: elaborated by the author, image base from Google Earth, 2015.

The forest (and the city).

Liedekerke is a small municipality on the Dender river between Ninove and Denderleeuw and about 25 kilometers west of Brussels. It held a crucial location as bridge town over the Dender river, one of the large south-north flowing rivers of the Scheldt basin. The town developed mainly on the east shore in between the river and the somewhat higher lying Liedekerke forest. The oldest accounts of the Liedekerke forest go back to the end of the Early Middle Ages. The first clear representation of its extent is the famous Ferraris map of 1775 a time in which the dispersed urbanization was already readable, but far from consolidated. This map [Fig. 2] is considered 
important because it might represent the last recorded spatial organization of a pre-industrial dispersed, yet quite sustainable territory that laid the base for current Flemish dispersion.

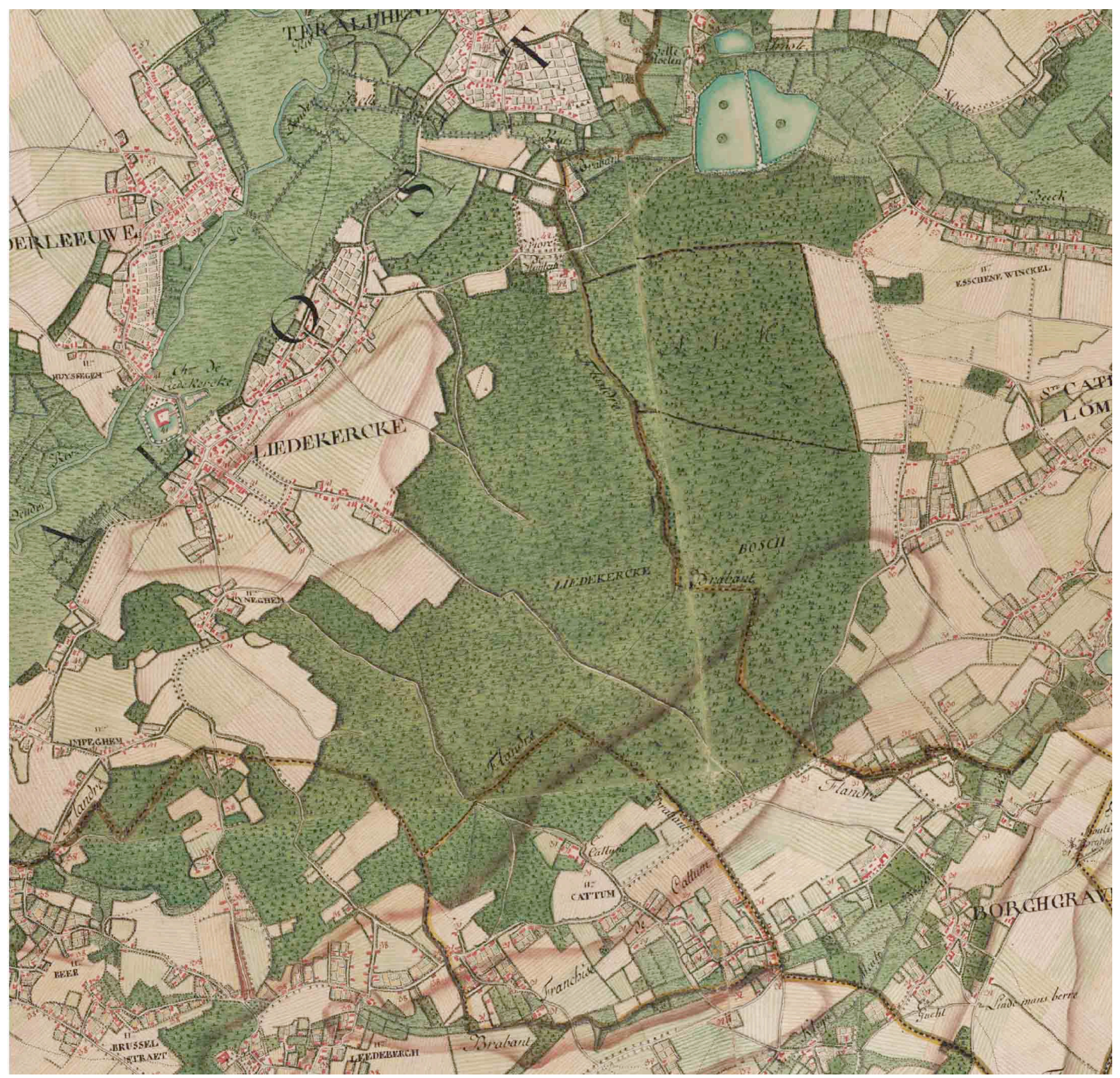

[Fig. 2] Ferraris map of 1775. The forest as one big mass. It forms a figure that is equal in size and strength as the Dender river. Liedekerke lies in between. This representation is important since it shows the earliest, precise geography of the forest in a moment where city and hinterland are still clearly defined entities, but where the base of the nebulous city is already existent. Source: (Lammens, 2011).

Although the Ferraris maps represent the forest as one continuous patch, it was never owned completely by a single person or entity. Different owners defined the faith and size of the forest over time and in space. The historic ownership dynamic is important to understand the forest's current situation. The forest knew a fractal ownership fragmentation comparable to Flanders' current ownership structure: from few owners with large surfaces to many owners that possess small surfaces. (Tack et al., 1993, Konijnendijk Van den Bossch et al., 2005, 12-14)

A first major division was the forest's location on the edge between the two regions, Flanders and Brabant. Although the borders between them were still shifting, they cut the forest administratively in two by the small stream - 'Hollebeek', or hollow creek - running south to north. Historically the lords of Liedekerke owned most of the Flanders part of the forest. Over time they donated pieces of the forest to the abbey of Ninove and had a cloister constructed in the southern piece called 'Monnikbos' - monk forest. Later they founded the cloister of Liedekerke in the northern part of the forest. (De Keersmaeker et al., 2011, 22-23) Because these religious 
establishments depended on the forest's products, they were either given pieces of the forest, or it was planted to generate this necessary life provision. Around 1790 the forest consisted of 220 ha possessed by the lords of Liedekerke, around $134 \mathrm{ha}$ by the cloister of Liedekerke and unknown surfaces by the cloister of Ninove (Monniken forest), and by the lords of Brabant (Hertighem forest) summing up to 880ha registered on the Ferraris maps. (Lammens, 2011, 25, De Keersmaeker et al., 2011, 25) In [Fig. 3] the forest names are geographically suggested. In his diary of 1815 the English General Mercer stationed in Strijtem mentioned how remarkable the persistence of the forest was in an area that was so densely inhabited. He immediately added that with the large scale hop growing and its continuous need for wooden poles, it was in fact not so remarkable that the forest played a fundamental role in the urban and rural life. (Heemkring Liedekerke, 2013, Cordemans, s.d.)

A number of events and laws proofed to be disastrous for the forest: the French Revolution in 1789 and the annexation of Flanders by France in 1795 resulted in the destruction and abandonment of the cloisters and the appropriation of their forests as royal domains. Unfortunately many were harvested for paying of, mostly military, debts in the turbulent succession from French to Dutch ruling and Belgian independency in 1830. In addition the ordinances on Wasted Lands from the Austrian Maria Theresia in 1772 (D'Alviella and Félix, 1927, 165) and the law on Wasted Lands from 1847 (Van Dijck, 2008, 161) stimulated the agricultural exploitation of land to counteract the famine. In the period from 1815 till 1880 the Liedekerke forest, as many other forests, was reduced to about a quarter of its size. The parcel plans from 1842 show how this systematic exploitation was organized. (Popp, 1842) A rational, orthogonal infrastructure grid grew from the surrounding streets into the forest and divided it in sellable parcels. This conjunction of orthogonal grids became the base for future urban development. The only piece of the forest that remained untouched was the privately owned Liedekerke forest between the small streams as shown in [Fig. 3]. ${ }^{1}$

\footnotetext{
${ }^{1}$ In 1775 the forst was 880ha; in 1847 about 410ha; in 1930 about 120ha; in 2001 175ha (boskartering). (De Keersmaeker et al., 2011, 25). In
} 1980 the forests reached its smalles surface with 77 ha forested surface. (Zwamvlok. Natuurpunt Denderstreek, 2015) 


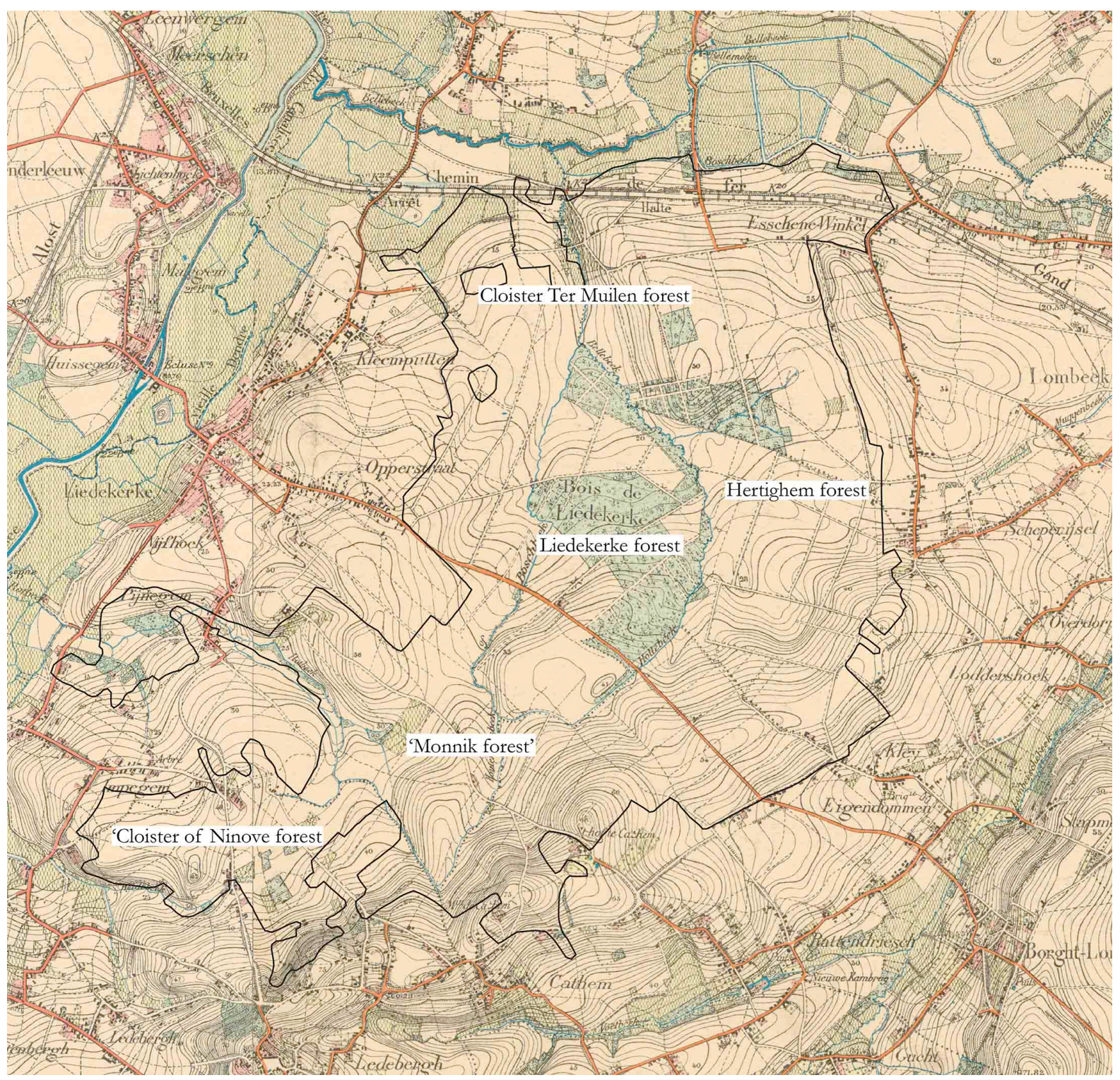

[Fig. 3] Topographic map from 1884 and 1891 edited together. The infrastructural grids used to harvest the forest are clearly readable in dotted line. These grids are skewed to connect to the surroundings and to follow the easiest topographic path possible. Source: elaborated by the author from (Militair Cartografisch Instituut, 1884) and (Militair Cartografisch Instituut, 1891).

In 1926 a part of the remaining forest was sold to the Radio and Television company - abbreviated R.T.T., current Belgacom - who installed a short wave for long range radio tower. For broadcasting purposes the forest was mostly kept low until its closure in 1972 after which maintenance was seized. In 1998 the Agency of Nature and Forest bought most of the land to establish a wild forest reserve. (De Keersmaeker et al., 2011, 24) The remaining piece of the original Liedekerke forest was acquired by a real estate company that intended to subdivide the forest into an allotment, yet was unsuccessful because of the completion of the land-use plan in 1975 fixing it as nature reserve destination. The land was finally sold to the Flemish Government giving the Liedekerke forest its current day existence. In [Fig. 4] a recapitulation of the deforestation phases is shown. 


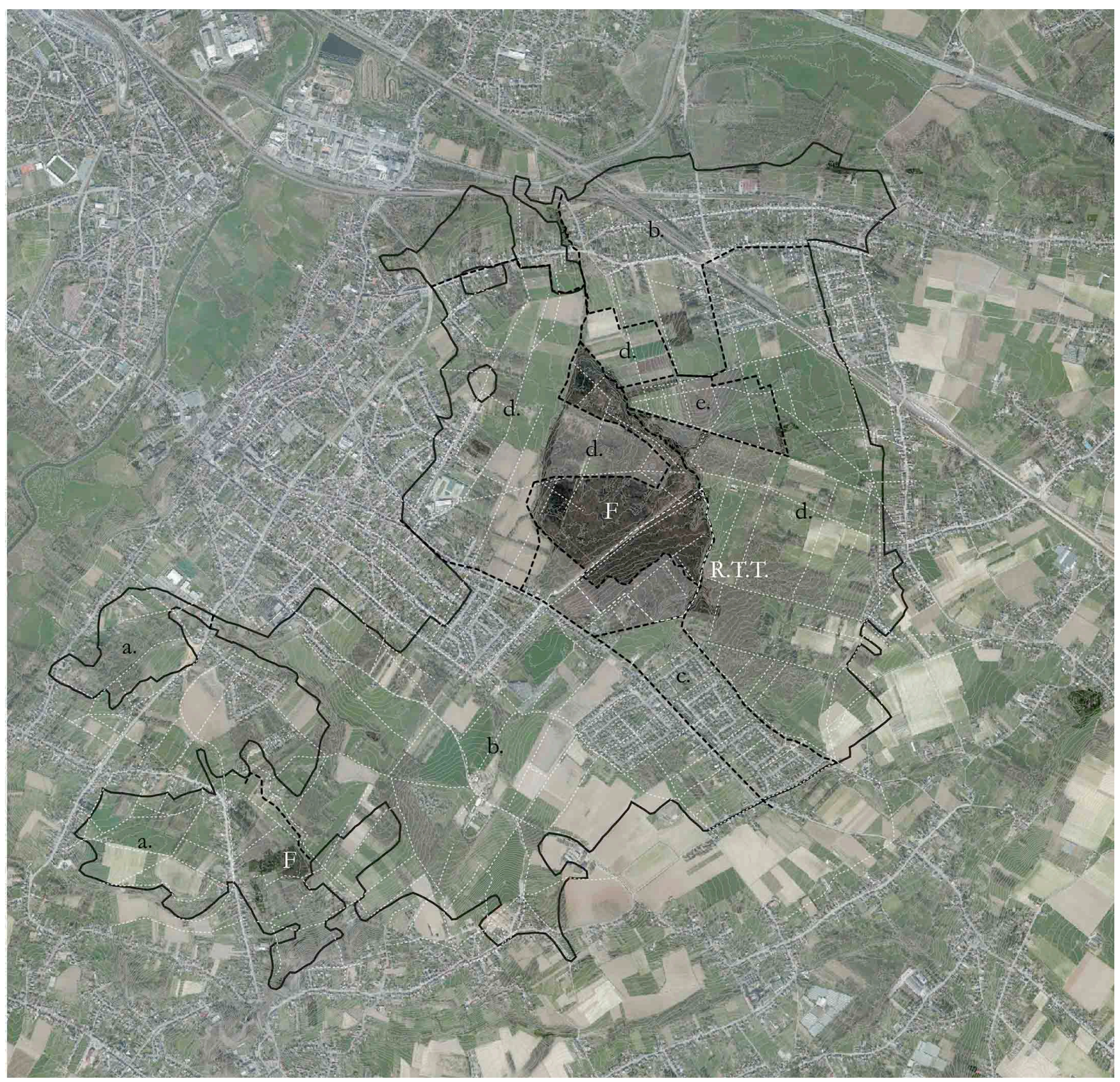

[Fig. 4] Deforestation succession over time and space. Legend: black, thick contour = Ferraris forest outline; thin, white, dotted line $=$ harvesting grids on topography; thick, white, dotted line $=23 \mathrm{ha}$ of former R.T.T. site, now forest reserve; bright aerial with white $\mathrm{F}=$ always has been, and still is, Ferraris forest (+- 60ha); deforestation phases: a. earliest harvests before 1815; b. harvest mainly from cloister demolition between 1815-1840; c. harvests around 1840-1850, became the spatial frame around which later the allotments of the 1970s where built, d. harvests from 1850-1900 reaching absolute minimum, e. piece harvested and afforested between 1850-1900. Source: elaborated by the author on Google Earth, 2015 map.

The forest talks about city.

This history of afforestation and deforestation reflected changing ownerships and interests in the forest, but in this evolution many influences on the urban structures go unnoticed. Abstractly one could describe the forest as the ultimate collector of ambiguities: the forest is the counter-figure - the ultimate nature - of the city, but glued around it are socially diverse urban classes in different housing typologies, making it highly urban itself; the forest is structured by natural streams and artificial orthogonal deforestation patches, but it is inside the artificial infrastructure, including the nature reserve in the former R.T.T. site, that the forest's ecology is rebuilt; the forest was highly embedded in the region's metabolism since it served the noble lords and clerks for peace, wood, hunting, currency etcetera, but also the poorest farmers collected fire wood and poles from the forest to cultivate hop on every square meter of their garden; finally the forest seems like a persistent, static entity, but it rather has been a continuously changing patchwork of land-uses that responded to the owner's necessities and the forest's opportunities. 
The identity of the forest as collector of ambiguities is being lost ever since urban planning fixed the landuses. It is very unlikely that the forest could regain its original size, dynamism, ecology and identity under these legal conditions, yet the forest's - with that we mean the at the time of Ferraris sized forest - particular spatial impact in the territory of dispersion can become the subject of five sustainable narratives. These do not attempt to rebuild the Ferraris forest in a miss-placed nostalgia for historic reconstruction, but search for the hidden potentials in the urban-forest realm to re-explore the multitude of meanings of the forest itself, and produce the nebulous city in its transition to a more sustainable future.

Narrative 1: the multi-modal landscape

One of the most fantastic aspects of the hidden Ferraris forest is its resistance against the infrastructuralization of the nebulous city. In the decades following the Second World War, the reconstruction wave changed the original city versus hinterland relation. The extremely isotropic road network reduces the amount of places that are not reachable by car to just a few while the new ecological awareness and traffic congestion tragedy call for new spaces where the car is abandoned, so called 'no-car' spaces. Yet in some pieces of the nebulous city the road network was never completed making these spaces authentic and automatically appropriate for a no-car vision. Namely in flood prone areas, steep slopes, valuable nature domains etcetera and also in the (former) Ferraris forests.

An analysis of current day infrastructure in Liedekerke forest, shown in [Fig. 5], learns that the roads have not completely penetrated the original forest as in other places of the nebulous city. As one draws closer to the former forest perimeter the roads turn narrower, less formal, un-serviced - no lighting or sewage - and finally unpaved and inaccessible. This gradual deconstruction of the nebulous city's base of existence introduces another living space and overall connectivity, and - for the nature lovers - a potential 'area of silence'2. The isotropic network dissolves into irrational, incomplete hierarchic branches with between them a well-composed intermediate figure: the set of orthogonal grids that rationally connect to the surrounding existing tissue, accommodated Liedekerke forest's piecemeal deforestation by selling the forest off in rectangular, sellable parcels. Pieces of the grid were then colonized by the 1970s allotments. [Fig. 6] shows the parcel plan illustrating its history. In the other places the grids provide the frame for the dynamic existence of agricultural activities - the 'kouters' or undulating agricultural fields - and forest. One of the examples is the replanting of Hertigem forest on the agricultural lands or through agroforestry as explored in the 'Plantage' workshop by Steunpunt Ruimte (Dehaene et al., 2015). It is important that these grid dynamics between forest, agriculture and the urban become more systemic.

\footnotetext{
${ }^{2}$ Stiltegebied
} 


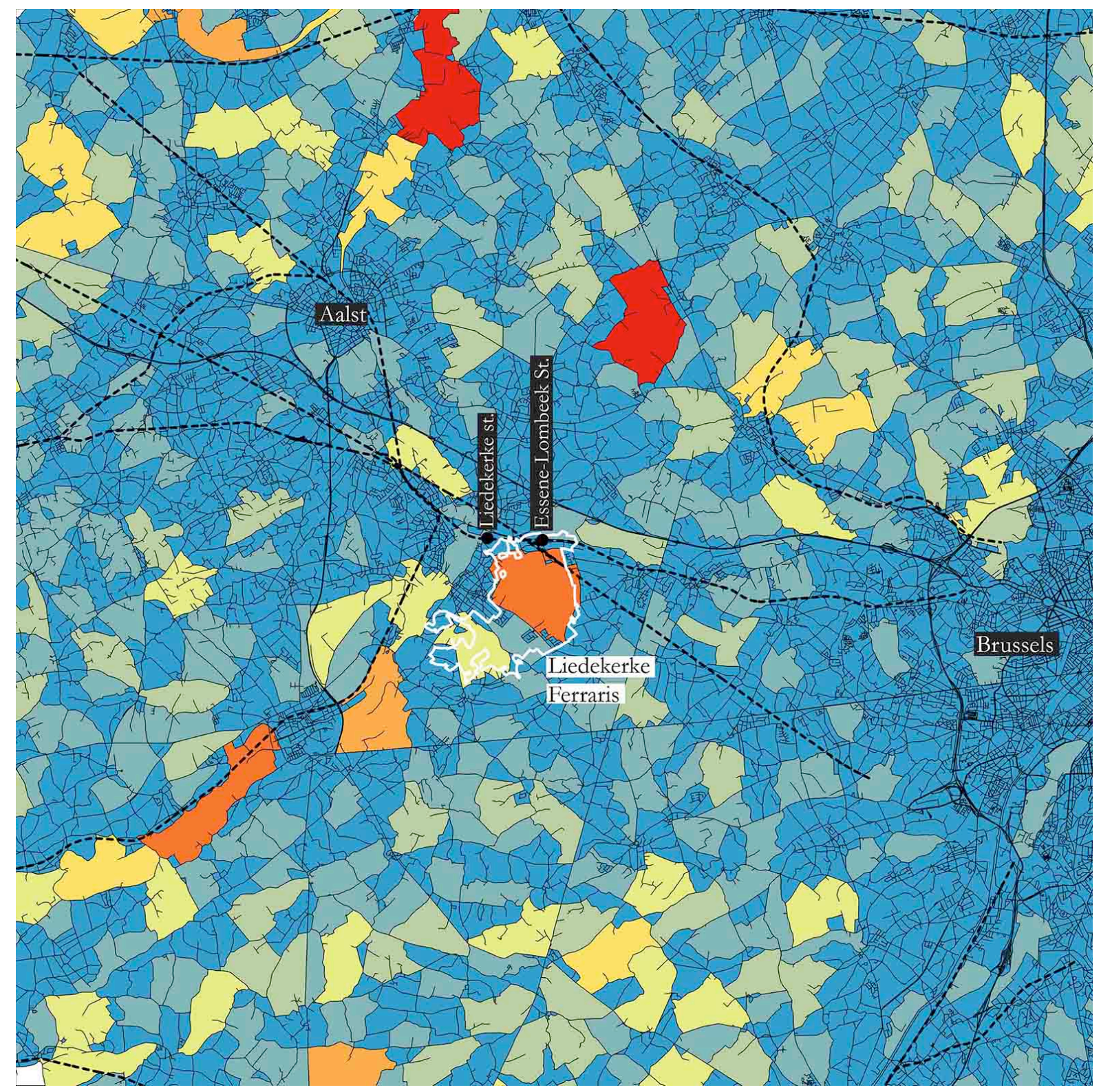

[Fig. 5] A piece of the nebulous city's road network between Aalst and Brussels. Where the forest used to be, the biggest gaps exist in the isotropic network. In this ArcGIS analysis polygons were made of the road network. The size (from small in blue, to large in red) is represented on the map. The red, orange and yellow areas are significant gaps and can be potential silent areas.

The rail network in thicker black lines show the connectivity through Liedekerke station (left one touching the Ferraris forest) and Essene-Lombeek (right touching Ferraris forest). These will become part of the RER network of Brussels. Source: elaborated by the author 


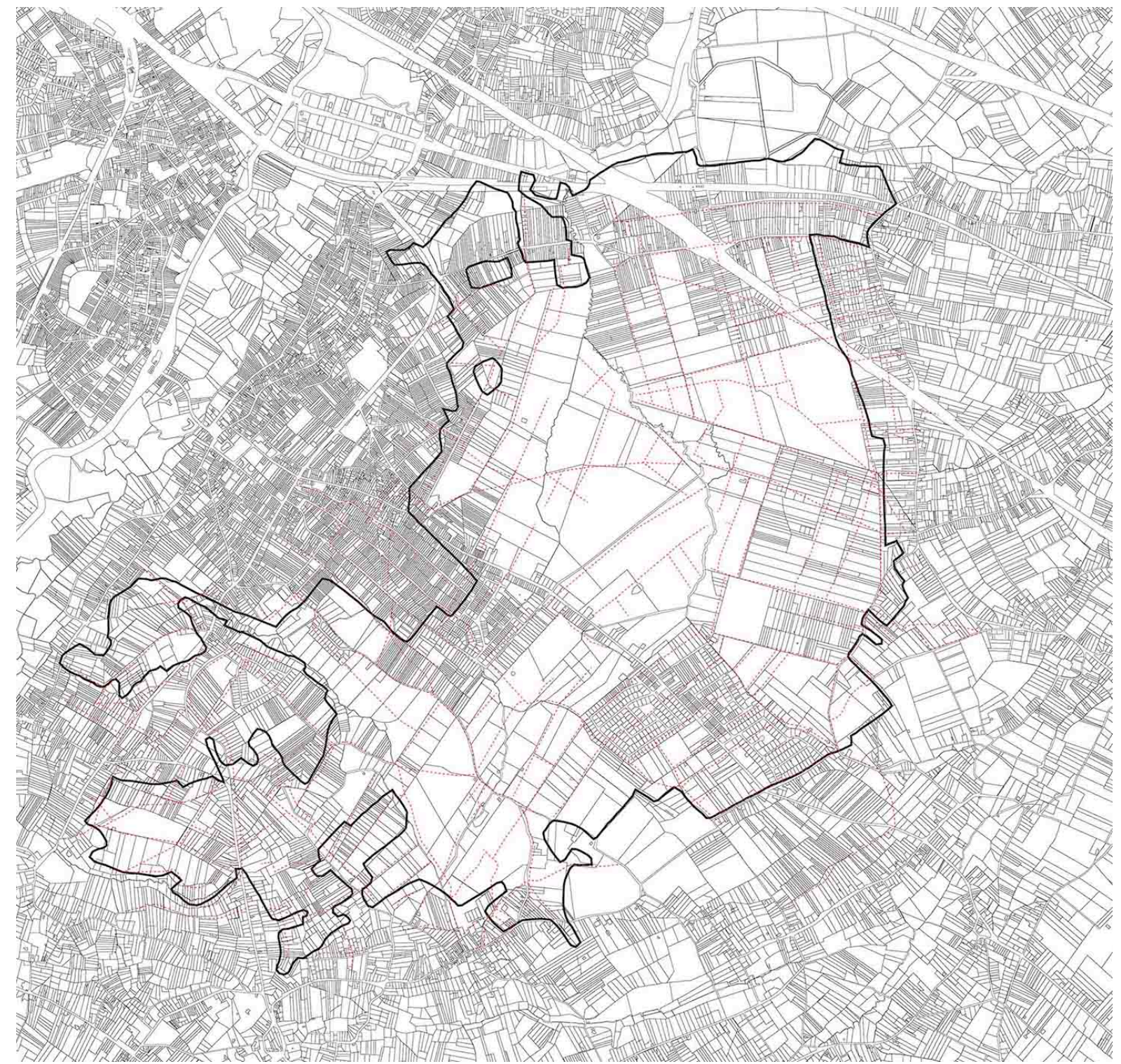

[Fig. 6] The parcel plan reflects the history of the site: the different forest harvesting grids in red coincide with the main parcel layout. Within the Ferraris forest outline the parcels are relatively large. Source: elaborated by the author

The hidden forest figure can become truly a sustainable example in the nebulous city. Where the car is left behind, other modes of transport take over. Biking and walking are now mainly associated with leisure activities, but the hidden forest figure should also be considered as an already established 'no-car' figure - as in the vision for Brussels 2040 of Bernardo Secchi and Paola Viganò. (Studio Associato Bernardo Secchi - Paola Viganò, 2012) where biking, walking and public transport (and horse-riding?) is the fundament of functional movements. The proximity of Liedekerke and Denderleeuw ${ }^{3}$ as urban cores with a certain density and presence of urban amenities, makes a soft mobility lifestyle perfectly possible. For long distance movements the stations of Liedekerke and Essene-Lombeek (and also Denderleeuw) hook directly onto the old forest perimeter and should be integrated much better within the forest lifestyle illustrated in [Fig. 5]

The hidden forest figure can be considered a hidden multi-modal landscape. The ambitions that the nebulous city aspires regarding soft mobility are all at hand. An intelligent recalibration of the exchanges and multi-

${ }^{3}$ The furthest distance from a forest edge location to Liedekerke is about 4 kilometre by bike or foot, and almost $50 \%$ more by car (circling the forest) 
modal systems that builds on a natural capital as a unique lifestyle and biotope ${ }^{4}$ could quickly meet the sustainable ambitions of the nebulous city.

\section{Narrative 2: the seed bank and DNA of the nebulous landscape}

Liedekerke forest's ecology is highly related to its history of changing land-uses. Four sub-ecologies are currently present in the forest: small patches and linear stripes along the streams have always been forest and show an ancient biotope; one 23 ha piece where ecological succession is tested by leaving it to nature's will; some of the orthogonal grids, as the former Hertigem forest, are being replanted with a well-intended afforestation program; finally some pieces have been deforested and used for agricultural purposes.

The Liedekerke forest is alleged to be part of the so called "coal forest" covering a large part of western Europe. (Zwamvlok. Natuurpunt Denderstreek, 2015) Indeed some, although very few pieces of the current forest have been forest for many centuries, but the forest stock has rotated many times. Where the forest has disappeared and agricultural practices were introduced, the soils were worked, turned over, exploited and fertilized over and over again. Almost none of the forest's original soils survived there. Where the forest persisted, or cut pieces were left as wasted lands, the ancient-old seeds remain hidden in the soil. The seeds exemplify the true ecology of the nebulous city since they represent a sample of what the territory inevitably would look like if left to nature's forces, also called the Potential Natural Vegetation, (Cornelis et al., 2009) but they also hold many rare species that are only visible in century-old soils as in Liedekerke forest. Along the Kruisbeek and Hollebeek streams some 'old-forest' species indicate the forest's continuous presence: the golden saxifrage (Chrysosplenium), the bluebell ${ }^{5}$ (Hyacinthoides non-scripta) and the wild garlic (or buckrams, ramsons; Allium ursinum). (De Keersmaeker et al., 2009)

Contradictorily the piece of forest where nature is completely left alone is where an urban installation fell into disuse allowing nature's return. The former R.T.T. site, intensively maintained during its usage, is reclaimed by nature since 1972. The Agency of Nature and Forest acquired the lands in 1998 and since then a none-maintenance policy is installed. These technics allow to observe how the pioneer birch-dominated forest gradually evolves into more shadow tolerant species. (De Keersmaeker et al., 2011) Also on the former Hertigem forest, the completely harvested piece in Flemish-Brabant, a new afforestation program was installed. Following the orthogonal infrastructure the forest is rebuilt through a number of social initiatives. Gradually different pieces of the original Ferraris forest are restored and made dynamic. In 2011 the forest even received the FSC label. (Schauvliege, 2012, 5)

Aside these public forest managements, the private owners also contribute largely to the establishment of the forest ecology. (Tack et al., 1993) A dialogue between the different forest owners, including the public sector, would allow for re-envisioning and re-invigorating the former forest ecology. It is absolutely critical to protect and build upon the nebulous city's seed banks so that its seeds can start migrating and not allow more ancient forest destruction as happened in Wilrijk in 2013..$^{6}$ (Belga, 2013) An alternative approach to dealing with the land-use plan, imagining land exchanges and land banks, allows for an intelligent construction of a unique, sizeable ecological biotope. The biotope realizes a new rich living environment for species - fauna, flora, but also for people - by using the lack of an established urban realm - as demonstrated in the first storyline - to introduce a large place dedicated to a wide variety of nature values.

\section{Narratives 3: to see and not to be seen ${ }^{7}$}

The forest possesses a bizarre range of intimacy and collectivity. In the same spatial frame of the forest one can choose to be completely isolated and alone, join together with others in intimate, collective moments organized by a clearing in the forest or a strategic spacing of the trees or choose the public activities organized by the competent governments. These qualities are exploited by functions in the nebulous city that need this context: the municipal cemetery Kruisbeekveld allows for introvert moments of peace; the manège 't Lindeken, a departure point for horse-riding, the ultimate return to a slower pace society; the Roosdaal camping site on the edge of the former Ferraris forest forms the dead-end where 'camp is set' as a base to explore the forest landscape; the public forest

\footnotetext{
${ }^{4}$ More on the specific ecological biotope in story 2: the seed bank and DNA of the nebulous landscape

${ }^{5}$ this is the flower that makes the Hallerbos (forest of Halle) so famous.

${ }^{6}$ In 2013 1,74ha Ferraris forest was destroyed for the construction of a logistical enterprise. This piece of forest would be compensated, but can never reach the richness that the destroyed Ferraris forest had.
}

${ }^{7}$ In analogy to the art installation the Gemeentelijke Academie voor Beeldende Kunst Liedekerke organised in the Liedekerke forest in 2012 called 'Transparant. To see through (the lens of, as a way of seeing) and the see through (as in literally seeing through something). 
entrances and play areas inside the forest; the hidden remnant of the cloister Ter Muilen that lies hidden between two majestic linden trees as protected heritage that serves for personal and more public pilgrimages (Erfgoed, 2015); etcetera as programs presented in [Fig. 7]

Unfortunately this richness of public, collective and intimate functions in the hidden forest figure often lie torn away from their context. The forest no longer embraces them. Their intimacy is only partially achieved by the relative remote location and small road accessibility. In addition the Agency of Nature and Forest promotes the most central piece of the existing forest as public playing ground, making most of the forest visible and public. On the other hand there are also pieces that are completely left to nature. The policy polarization - the choice between pure, uninterrupted nature or the ultimate leisure experience - makes the difference nuances of the forest difficult to achieve and causes a certain reduction in the diversity of atmospheres. The ambition of the hidden forest figure is to re-establish this bizarre range of seeing and not being seen, of visibility and transparency, of intimacy and collectivity.

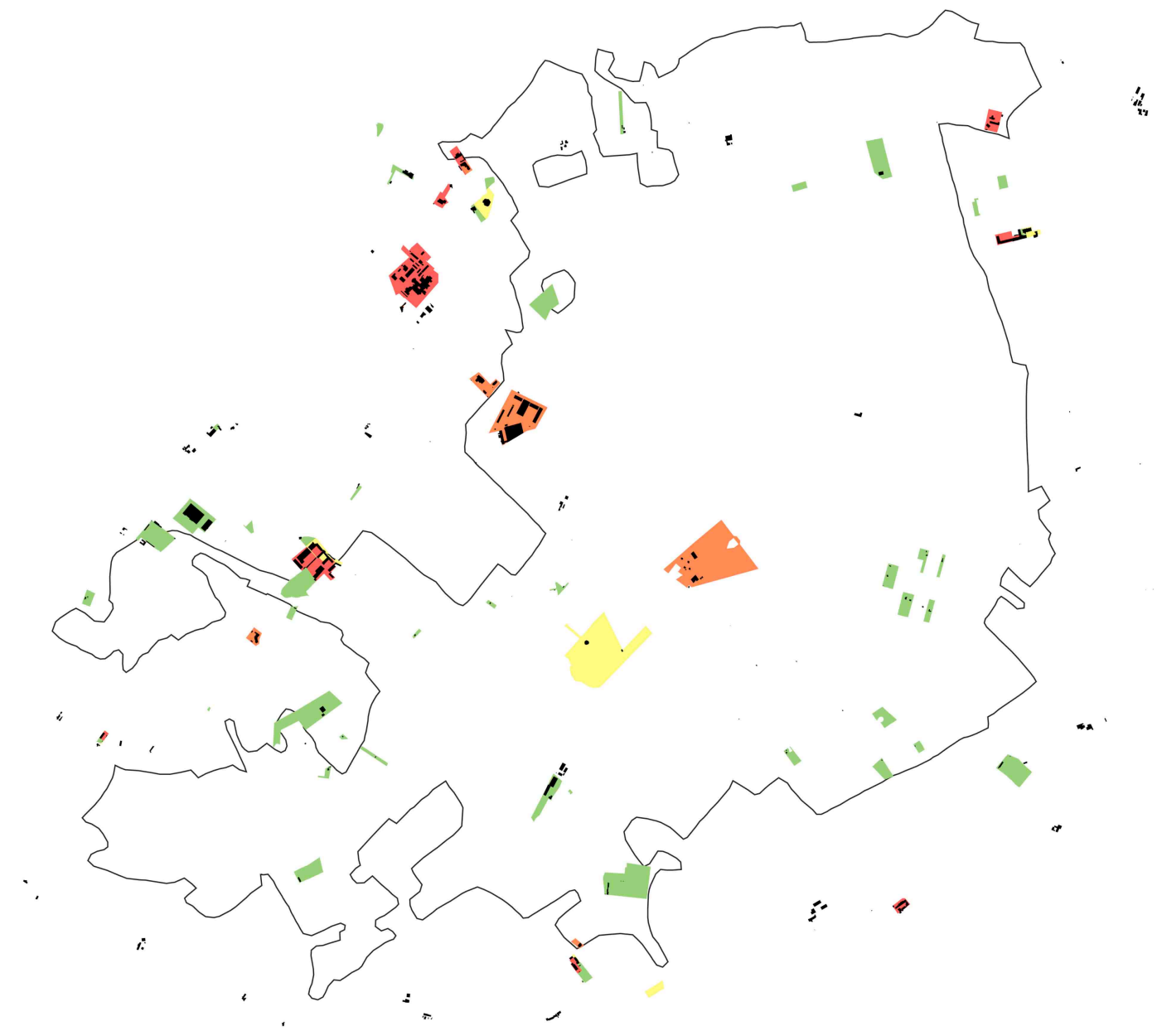

[Fig. 7] Programs in and around the former Liedekerke Ferraris forest. Legend: green = leisure functions; yellow = castles, religious installations; orange $=$ health and public importance; red $=$ education and culture. The leisure functions are more evenly spread and present. Source: elaborated by the author

Narratives 4: finally, that Flemish dream

Historically the forest was not the place for housing except for large mansions for the noblemen and the cloisters, abbeys and other religious installations. Only the poorest amongst the poor often searched the edge of the forest to enjoy whatever the forest owner could spare. (Tack et al., 1993) In Liedekerke one road crossed straight through the middle of the Ferraris Liedekerke forest. The 'opperstraat' - originally called "brusselstreate" indicating the route to Brussels, the street changed name due to the hop that was cultivated abundantly on the street (Heemkring Liedekerke, 2013) - was one of the only East-West road that didn't follow the Dender's North-South logic and proved to be most dynamic and mixed. In the $18^{\text {th }}$ Century the local population were given authority to collect deadwood. To avoid long distances the poorest would settle at the edge of the forest along the East-West street that 
extended towards the forest. With time the small houses grew deeper away from the street resulting in a system of 'kasjkes' or small perpendicular streets that brought together collectives of people and families. (Smet, 2013) This micro-urbanism - narrow streets, small and chaotic, eclectic buildings - allowed the successive appropriation by the poorest people. During the Industrial Revolution the wood houses were upgraded to stone worker houses and afterwards they followed the different style periods. These streets, or rather paths, bundle Flanders' eclectic built patrimony in one eye catcher, captured in [Fig. 8]. The fattening ribbon development finally detached from the regressing forest and lost its original, geographic rationality.

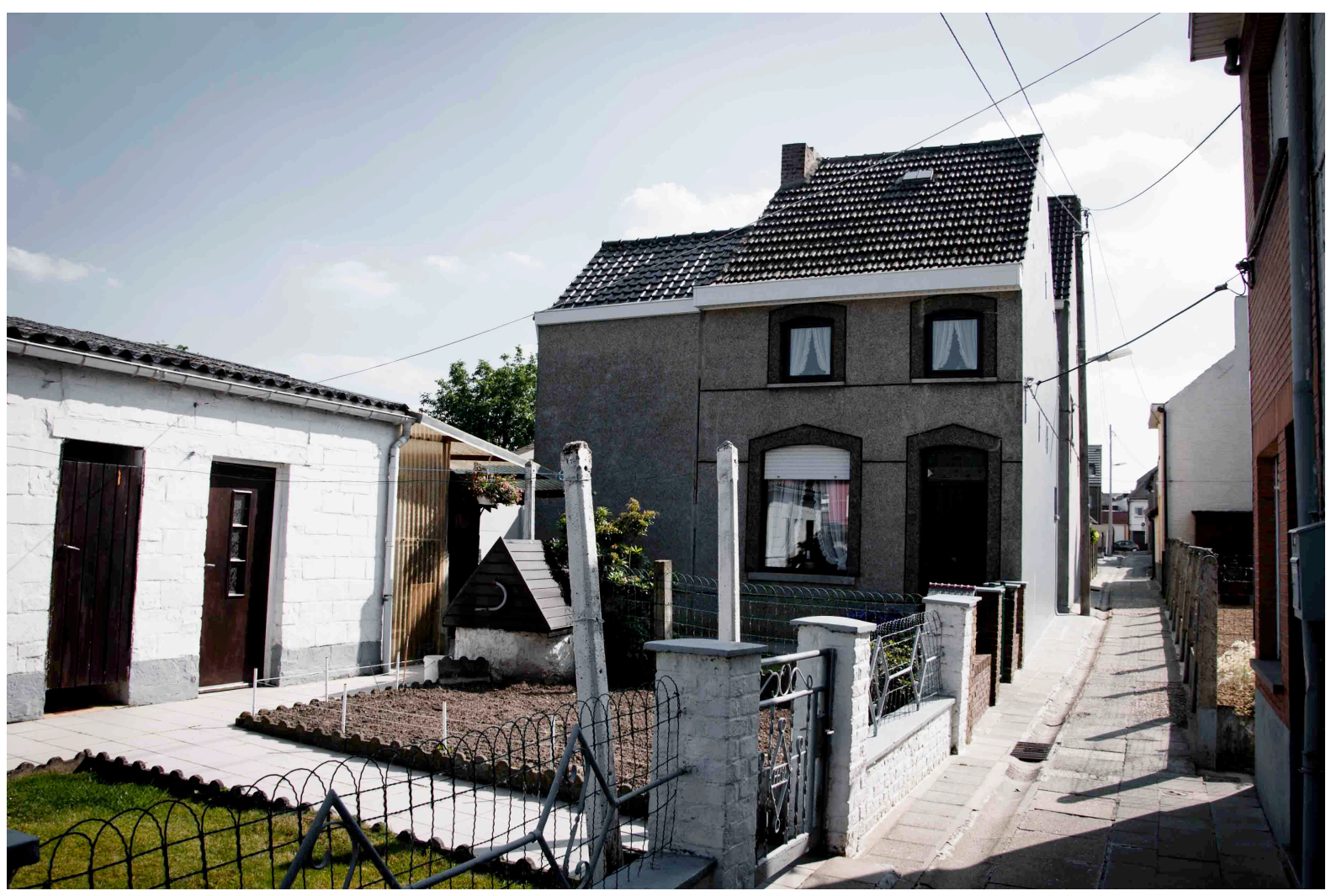

[Fig. 8] Foto of one of the 'kasjkes' in Liedekerke. Notice the narrow street and eclectic architecture. Source: (Regionaal Landschap Pajottenland en Zennevallei, 2014)

Yet, another fundamental change in attitude towards the forest arose in the spirit of the early $20^{\text {th }}$ Century. The forest became appropriated with leisure, health and education infrastructure as a reaction to the suffocating city. Mainly during the Interbellum, ${ }^{8}$ the forest started to be systematically colonized by temporarily inhabited holiday houses that quickly turned permanent. This fundamental urban colonization brought a mental change. The forest was no longer the counter-figure of the city, but rather an interesting, and more healthy alternative.

Where this colonization was still prude before the Second World War, afterwards the speculative nature of the real estate market, the stimulation of the ultimate dream of "owning your house with a garden in the hinterland" and the lack of planning regulation lead to an allotment boom. Many forests were partially eaten by the profit driven developers and their monotonous allotments. It probably was the most disastrous housing boom of Belgium due to its complete lack of typological innovation, its scale - in the 1950s, 1960s and 1970s the building speed was the highest ever (Belgian Federal Government, 2013) - and the lack of urban quality. They deliberately searched nature, but their invasion into it was apathic, disrespectful and destructive. The forest was one of their main victims. Ironically many of these allotments carry names of trees, flowers, birds...9

Today the spatial frame of Liedekerke is more or less consolidated and soon the housing reserve areas will be opened for development. After a number of forest related developments, a new moment of convergence

${ }^{8}$ Period between the two World Wars, 1920s and 1930s.

${ }_{9}$ Amongst the street names of the allotments in Liedekerke are: Populierenlaan, Begonialaan, Eikenlaan, Zwaluwenlaan, Beikenelaan, Dennenlaan, Notelarenlaan, Wilgenlaan, Fazantenlaan, Meeuwenlaan... 
between urban and forest development is needed. Different opportunities and tendencies direct towards it. Firstly all the housing expansion areas of the municipalities, and some of the surrounding municipalities, are located within or on the edge of the former Ferraris forest, as shown in [Fig. 9]. Through these expansion areas building houses and planting forest should go hand in hand to recreate a rich forest-urban interface. The time that urban development disconnects completely from its territorial base is over. Secondly, the hidden forest figure contains a varied social composition, as (partially) illustrated in [Fig. 10]. The forest therefore contains an intrinsic capacity to allow a high urban integration and build a housing stock that serves the new societal configuration. (Winters and De Decker, 2009) Finally as stated in the previous stories, the hidden forest figure holds the immediate potential to become a sustainable nebulous figure. It is here that new innovative housing initiatives, and even densification, could grow based on soft mobility, public transport and an intense density of high quality of life programs in an incredible forest landscape setting. Together they potentially stage the perfect atmosphere for a fantastic new urban realm. Finally, that Flemish dream.

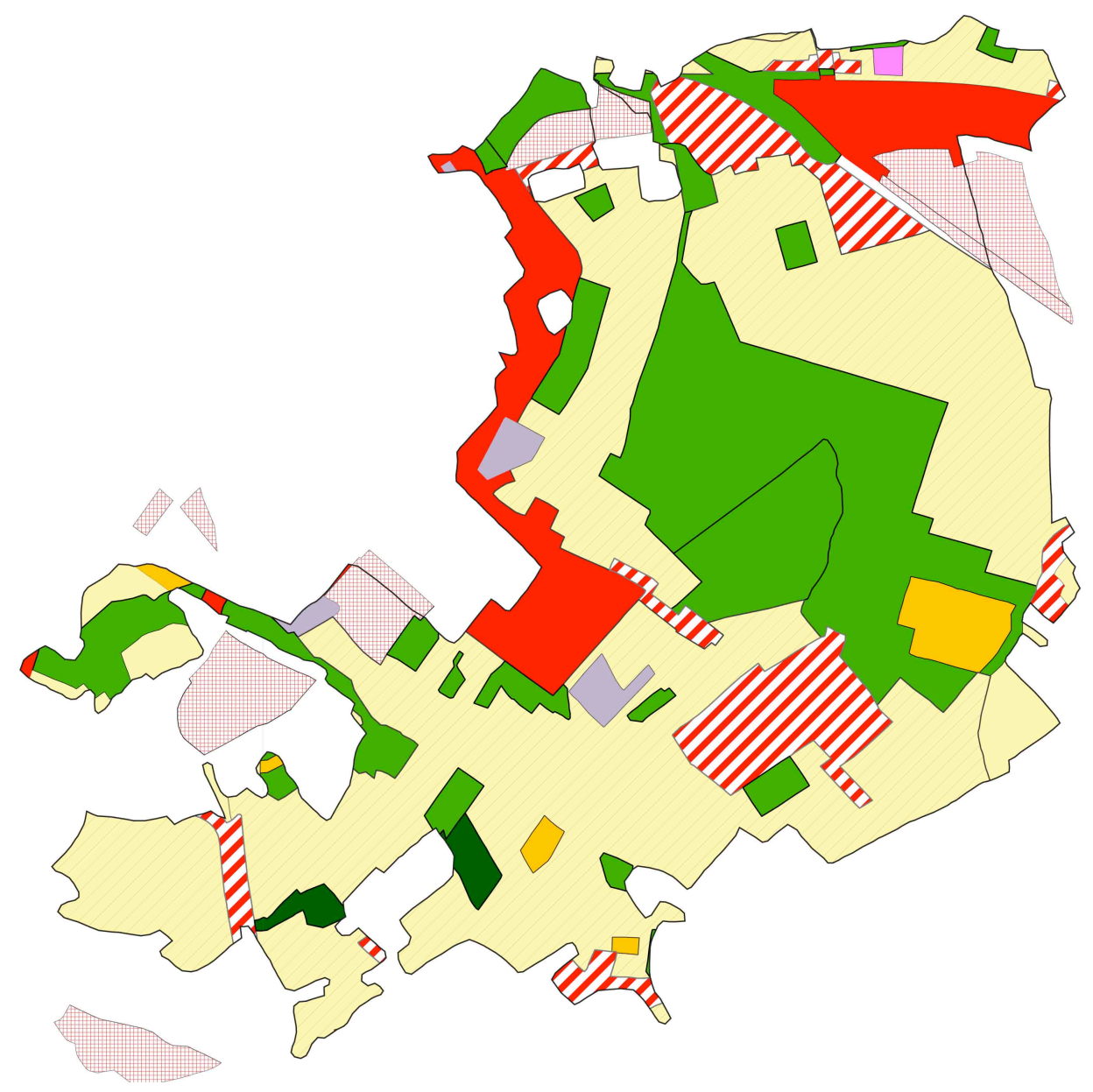

[Fig. 9] Housing expansion areas and the hidden forest figure. The land-use is very fragmented with actually very few true forest (dark green). The current Liedekerke forest is 'nature area'. The housing expansion areas (squared red with white background) are all located along or in the former Ferraris forest. Source: elaborated by the author from (Ministerie van openbare, 1972) 

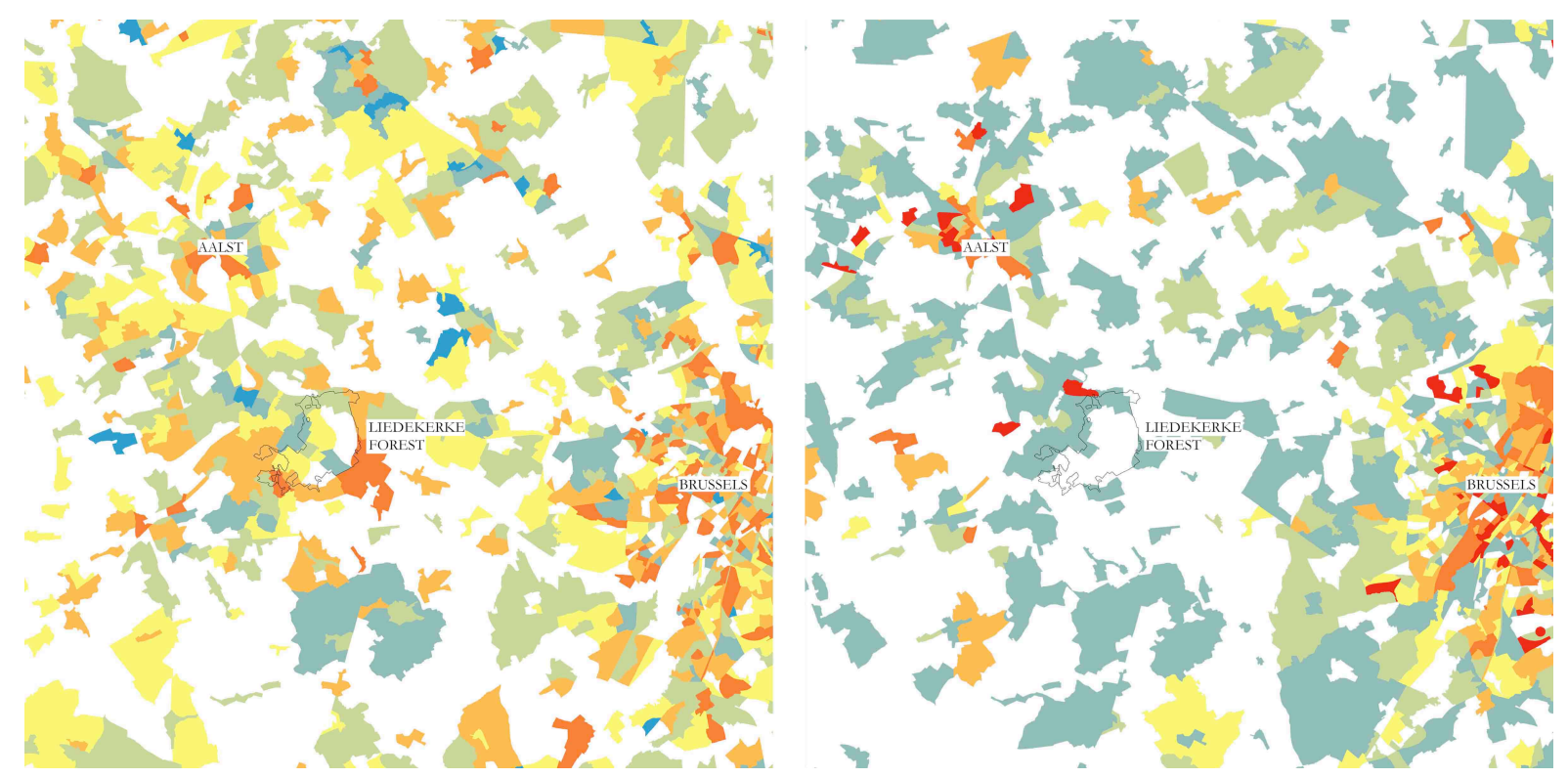

[Fig. 10] This double figure shows the Liedekerke forest in black outline. On the left the average income of the statistical zone from blue (high) to red (low). On the right the relative amount of foreigners per statistical zone from red (high) to blue (low). White values are too low to be statistically relevant. In both cases Liedekerke forest shows a certain degree of mixity. Source: elaborated by the author from data from the Nationaal Geografisch Instituut, 2015, consulted on 31 ${ }^{\text {st }}$ of August.

\section{Story 5: a bidden forest practice}

The 1970s land-use plans (Ministerie van openbare, 1972) fixed the destination of the hidden forest figure resulting in the reduction of flexibility and variation, shown in [Fig. 9]. The ecosystem of a forest is a continuous carpet of diverse conditions: wet to dry, sand to clay, high to low vegetation, dens to open vegetation... The forest contains a multitude of landscape gradients that allow a multitude of life styles. This diverse forest architecture has to be built just as the different functions that the forest houses. And so beyond the 'untouchable' ecology and public leisure function of the remaining Ferraris forest, there is space for designing the forest for a multitude of urban appropriations. Nowadays the Agency of Nature and Forest orients the forest design largely towards establishing an authentic forest ecology and, with merit, they slowly succeed in recovering some of the ecology that was lost over the decades of nebulous city development. Unfortunately their effectiveness often depends on the Agency acquiring the land while this technic is out-dated. In a spread urban condition where land prices are exuberantly high, it is fair to say they will not be able to establish nearly as much nature as they need to by applying their land acquiring policy.

To be able to exploit the potential richness of the forest more actors need to be involved in forest building. This will prove much more efficient in realizing the forest and its ecosystem (including fauna, flora, people). The hidden forest figure - the 1775 Ferraris forest border - could serve as an intermediate area of collaboration. Based on the history of Liedekerke and its forest it is fair to say that a fundamental different, sustainable piece of nebulous city can be built when reconsidering how projects within this hidden figure are realized. A central committee could be installed that represents the most important actors within the hidden figure: the Agency of Nature and Forest, the urbanism departments of the municipalities Liedekerke and Ternat, a representative of the Flemish government concerning urbanism and soft mobility... All projects that are realized should be discussed and negotiated by the committee so that they can streamline new urban-forest interfaces. Liedekerke forest would then be co-produced as an integrated ecosystem where forest can co-exist with its users. This approach potentially annihilates the historic inversed urban-forest relation - where urban grows, the forest disappears - but established them as inseparable entities.

\section{Conclusion: forest urbanism in the nebulous city}

The case of Liedekerke forest and its five stories presents a discourse on how to actually advance with the transition of the nebulous city towards a more sustainable model. Intermediate (landscape) figures can be strong operators that allow a unique co-produced urban realm. The strength of this approach is the relative evident quality that the forest possesses, but that remains completely underused due to structure of sectorial competences. Looking at the exchanges between urban and forest in their historic evolution, it is fair to say that establishing nature is not only possible through an Agency of Nature and Forest. Vice versa the urban realm can no longer be produced only by urban administrations since it resulted in detached, grey, monotonous living conditions. 
The hidden forest figure holds an intrinsic capacity to build pieces of unique urban realm in the nebulous city. The Liedekerke forest is one of many forests that remain hidden in the nebulous city's web of streets, as [Fig. 11] shows. Its strategic location between Gent, Aalst and Brussels could make this case exemplary for other forest figures. Together they can become a practice of a new (forest) urbanism that significantly contributes to the nebulous city's transition to a more sustainable model.
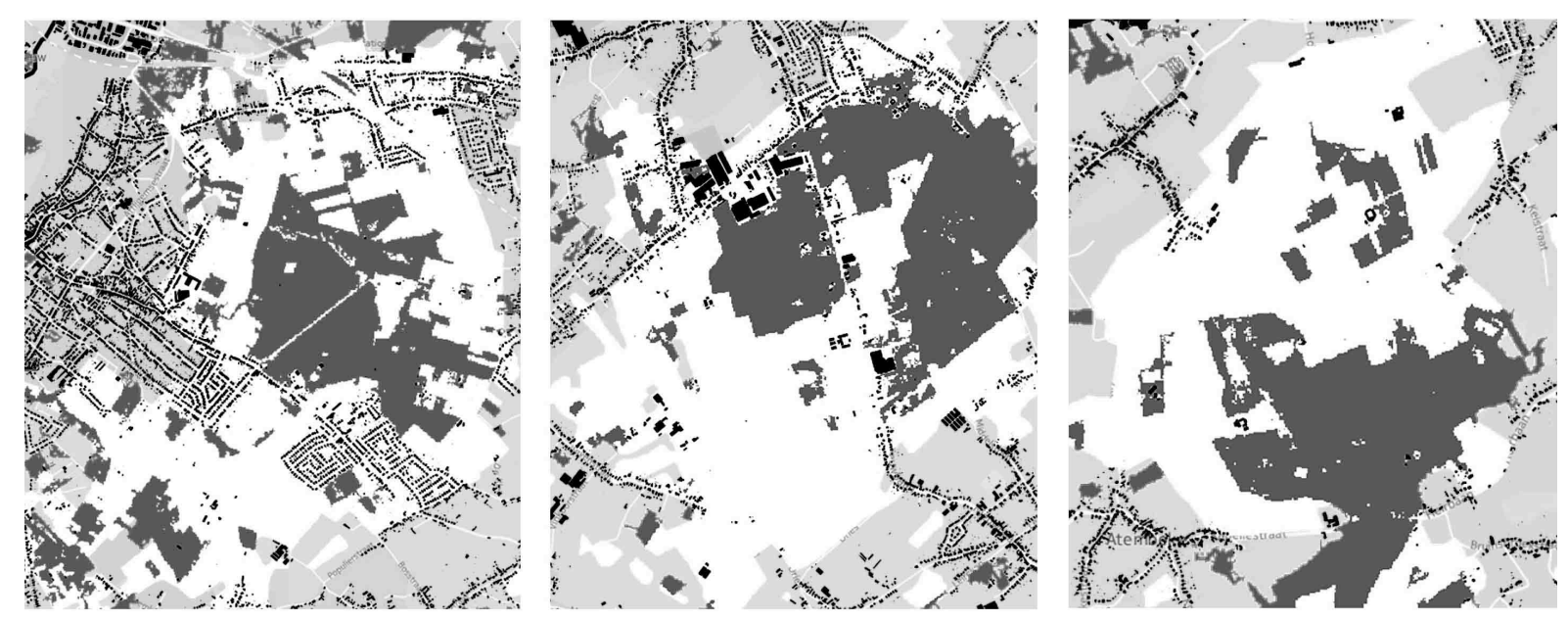

[Fig. 11] Hidden forest figures: Liedekerke forest; Buggenhout forest in Buggenhout; Moerbeke forest in Geeraardsbergen. White background shows the 1775 Ferraris forest, dark grey current forest. Source: (Vanderfaille, 2015, 82-83) 


\section{References}

BELGA. 2013. Politie ontruimt bezet Ferrarisbos in Wilrijk. Het Laatste Nieuns.

BELGIAN FEDERAL GOVERNMENT. 2013. Statistics Belgium - Het Gebouwenpark [Online]. Brussel: Belgian Federal Government. Available: http://statbel.fgov.be/nl/statistieken/cijfers/economie/bouw_industrie/gebouwenpark/ [Accessed 27/08/2015 2015].

BERGER, A. 2006. Drosscape : wasting land in urban America, New York, Princeton Architectural Press.

CORDEMANS, M. s.d. De Engelschen in Vlaanderen in den tijd van Wellington : wit het dagboek van generaal A. C. Mercer, Dendermonde, Dendermonde Het Ros Beiaard, s.d.

CORNELIS, J., HERMY, M., ROELANDT, B., DE KEERSMAEKER, L. \& VANDEKERKHOVE, K. 2009. Bosplantengemeenschappen in Vlaanderen: een typologie van bossen gebaseerd op de kruidlaag, Brussel, Brussel Agentschap voor Natuur en Bos, 2009.

D'ALVIELLA, G. \& FÉLIX, A. J. 1927. Histoire des bois et forêts de Belgique : des origines à la fin du régime autrichien, Bruxelles, Bruxelles : Lamertin, 1927-1930.

DE KEERSMAEKER, L., CHRISTIAANS, B., ESPRIT, M., LEYMAN, A., VAN DE KERCKHOVE, P. \& VANDEKERKHOVE, K. 2011. Bosreservaat Liedekerkebos. Evolutie van het onbeheerde bos en evaluatie van een experiment om heischraal grasland te herstellen. In: INSTITUUT VOOR NATUUR- EN BOSONDERZOEK, I. (ed.). Geraardsbergen.

DE KEERSMAEKER, L., VANHELLEMONT, M. \& VANDEKERKHOVE, K. 2009. Een balans van 20 jaar spontane bosontwikkeling in Liedekerkebos. In: INSTITUUT VOOR NATUUR- EN BOSONDERZOEK, I. (ed.). Geeraardsbergen.

DE MEUlDER, B. \& DEHAENE, M. 2001. Atlas Zuidelijk West-Vlaanderen. Fascikel 0\&1, Anno '02 \& CaD (Kortrijk).

DEDECKER, P., MEULEMANS, B. \& GEURTS, V. 1997. Trouble in paradise? On increasing Housing Problems in Flanders. Journal of Housing and the Built Environment, 281-305.

DEHAENE, M., DE KOOL, D. \& DUMONT, M. 2015. Workshop: de plantage. Leuven: Steunpunt Ruimte.

ERFGOED, O. 2015. Twee kapellindes bij de Onze-Lieve-V rouw-ter-Muilen (ID:3371) [Online]. Brussel. Available: https://inventaris.onroerenderfgoed.be/ile/boom/3371 [Accessed 29/08/2015 2015].

HEEMKRING LIEDEKERKE, L. H. V. 2013. Hopteelt in Liedekerke [Online]. Available: http://www.heemkringliedekerke.be/hopteelt-in-liedekerke [Accessed 26/08/2015 2015].

KONIJNENDIJK VAN DEN BOSSCH, C. C., NILSSON, K., RANDRUP, T. B. \& SCHIPPERIJN, J. 2005. Urban forests and trees, Berlin, Berlin : Springer Verlag, 2005.

LAMMENS, S. 2011. De grote atlas van Ferraris: de eerste atlas van België [1:25.000], Tielt, Tielt Lannoo, 2011.

LIEDEKERKE, G. 2012. Transparant. Kijken door - Doorkijken [Online]. Liedekerke. Available: http://www.liedekerke.be/content/content/record.php?ID=2399\&s_navID=642 [Accessed 29/08/2015 2015].

MILITAIR CARTOGRAFISCH INSTITUUT. 1884. Militaire kaarten van Ninove. XXX, 1:20000. Brussel.

MILITAIR CARTOGRAFISCH INSTITUUT. 1891. Militaire Kaarten van Assche. XXXI, 1:20000. Brussel.

MINISTERIE VAN OPENBARE, W. 1972. Arrêté royal du 28 décembre 1972, relatif à la présentation et à la mise en oeuvre des projets de plans et des plans de secteur. Koninklijk besluit van 28 december, betreffende de inrichting en de toepassing an de ontwerpgewestplannen en de gewestplannen, Brussel, Brussel : Ministerie van openbare werken, 1972?

PELLEGRINI, P. \& VIGANÒ, P. 2006. Comment vivre ensemble: prototypes of idiorrythmical conglomerates and shared spaces, Roma, Roma Officina edizioni, 2006.

POPP, P.-C. 1842. Liedekerke [1:5.000]. Bruges: Bruges Popp, tussen 1842 en 1879.

REGIONAAL LANDSCHAP PAJOTTENLAND EN ZENNEVALLEI 2014. Liedekerkse kasjkes. In: DSC0463.JPG (ed.). Liedekerke.

RYCKEWAERT, M., DE DECKER, P., WINTERS, S., VANDERKERCKHOVE, B., VASTMANS, F., ELSINGA, M. \& HEYLEN, K. 2012. Een woonmodel in transitie: toekomstverkenning van het Vlaamse wonen, Antwerpen, Antwerpen Garant, 2012.

SCHAUVLIEGE, J. 19/06/2012 2012. RE: Liedekerkebos/Hertigembos - Ternat.

SMET, P. 2013. Publiek Geheim: Liedekerke, Moeder der verkavelingen, bakermat van de 'Kasjkes'. Penæine. Pajottenland en Zennevallei Magazine. Halle: Toerisme Pajottenland et Zennevallei, Regionaal Landschap Pajottenland et Zennevallei, Erfgoedcel Pajottenland et Zennevallei, Pajottenland +.

STUDIO ASSOCIATO BERNARDO SECCHI - PAOLA VIGANÒ 2012. The Horizontal Metropolis. In: DEJEMEPPE, P. \& PÉRILLEUX, B. (eds.) Brussel 2040: drie visies voor een metropool. Brussel: Brussel Brussels hoofdstedelijk gewest, 2012.

TACK, G., VAN DEN BREMT, P. \& HERMY, M. 1993. Bossen van Vlaanderen : een historische ecologie, Leuven, Leuven : Davidsfonds /Print : Lannoo (Tielt), 1993.

VAN DIJCK, M. 2008. De wetenschap van de wetgever: de klassieke politieke economie en het Belgisch landbouwbeleid, 1830-1884, Universitaire Pers Leuven. 
VANDERFAILLE, M. 2015. Latente structuren in de Vlaamse nevelstad: het discontinue lint als leidinggevende structuur in de beekvallei. Master of Architecture, KULeuven.

VLAAMSE OVERHEID 1991. Bosdecreet, Brussel, Brussel Ministerie van de Vlaamse Gemeenschap. Dienst Waters en Bossen, 1991.

VLAAMSE OVERHEID, D. 2011. Ruimtelijk structuurplan Vlaanderen, Brussel, Brussel : Ministerie van de Vlaamse Gemeenschap. Afdeling ruimtelijke planning, 1998.

WINTERS, S. \& DE DECKER, P. Wonen in Vlaanderen: over kwaliteit, betaalbaarheid en woonzekerheid. 2009.

ZWAMVLOK. NATUURPUNT DENDERSTREEK. 2015. Paddenstoelenwerkgroep Zwamvlok. [Online]. Available: http://www.zwamvlok.be/component/content/article/51-gebieden/64-liedekerkebos.html [Accessed $27 / 08 / 2015$ 2015] 